\title{
The economic debate on power: A Marxist critique
}

\author{
Giulio Palermo* \\ Department of Economics, University of Brescia, via S. Faustino 74, 25122 Brescia Italy
}

\begin{abstract}
In the economic debate on power, seemingly opposite positions have been presented. Contractualists have claimed that power relations do not exist in capitalism, and radicals have maintained that they are ubiquitous. In the middle, transaction costs and property rights economists have argued that power relations exist only within the firm. The underlying conception, however, is the same: power is an interpersonal relation caused by imperfections in the decision-making context and is incompatible with Walrasian competition. The difference among these theories involves their viewpoints on the concrete spread of imperfections in reality. The thesis of this paper is that this narrow conception of power is a consequence of neoclassical methodology. Following Marx, I analyze power as a social relation, and I discuss three problematic aspects of the neoclassical conception: its individualistic methodology, the assumption of universal rather than historical categories, and an ontology that conflates production and circulation.
\end{abstract}

Keywords: Power, Walrasian competition, Methodological individualism, Production and circulation, Imperfections, New institutionalism, Radical political economics, Marx.

JEL codes: L220; D230; B210

\section{Introduction}

The role of power in economics came to the forefront of the academic debate in the seventies, mainly as a byproduct of the debate on the nature of the firm, with contrasting contributions from Stephen Marglin $(1974,1975)$ on the one hand and Alchian and Demsetz (1972) on the other. The former argues that power relations play a decisive role in the organization of the firm; the latter contend that formal authority within the firm is only an appearance that hides a reality of perfect reciprocal freedom. However, Ronald Coase's (1937) paper on the nature of the firm is in the background. In this paper, Coase explicitly sets the mechanisms of authority and command within the firm against the market price mechanism as alternative modes of coordination.

Recall that Coase's paper is not about the nature of capitalist power relations; rather, it addresses "the nature of the firm" in capitalism. From a Marxist perspective, such a problem may appear trivial because the firm is an integral part of the capitalist system. Therefore, Marxists suggest that by analyzing the historical origin and developments of capitalism one can understand the nature of the firm and of the other institutions of capitalism.

This problem, however, is anything but trivial if it is placed within the context of neoclassical economics, a context in which economic institutions are seen as universal and everlasting, like the economic problem they solve: the allocation of scarce resources. In neoclassical economics, the firm and the market are two alternative allocative mechanisms. The theoretical problem is that in the general equilibrium model, coordination between 
isolated individuals, both in the sphere of production and in that of consumption, occurs entirely within the market, which makes all other institutions economically redundant. The story told to describe the general equilibrium model sometimes refers to the firm and to other institutions (such as the family), but analytically, they are superfluous add-ons. This leaves the internal relations of the firm undetermined. As Paul Samuelson $(1957$, p. 894) put it, "In a perfectly competitive model, it really doesn't matter who hires whom; so let labor hire capital."

The general equilibrium model, like any theoretical model, is defined by a "decision making context" (DMC) and an "organizational structure" (OS). The former defines the features of the world in which agents of the model live and interact; the latter defines the relations among them and the way in which they interact. The DMC of the Walrasian model is characterized by perfect information, full rationality, and zero transaction costs. In this paper, I will refer to it as the "perfect" DMC. The OS is completely decentralized, based on market relations and perfect competition.

Starting from the fact that the firm is redundant within the Walrasian model, Coase raises two scientific questions: Why do hierarchies exist in the market system? What is the source of power relations within the firm? These questions can be approached in many ways. Coase's method consists of exploring the reasons why authority and direction may be economically superior to market relations in a context of positive transaction costs. Methodologically, Coase rejects the perfect DMC and investigates how OSs with some degree of centralization might perform better than the Walrasian one. Within this logic, Coase's explanation of the nature of the firm insists on the existence within the firm of a relation of formal authority that is absent in the market. Thus, in one way or another, Coase introduces a form of power in the neoclassical model and uses it to analytically characterize the firm as an institution that is qualitatively distinct from the market. If power is the ability to condition the behaviors of other individuals, then authority is the strongest form of power because it implies that one subject orders and the other obeys.

Theoretically, the introduction of authority as a specific coordination mechanism operating within the firm solves the problem (the nature of the firm). However, it disrupts the harmonious vision of interpersonal relations provided by Walras' model. From the viewpoint of the liberal doctrine, the problem is thus to reconstruct a harmonious vision of spontaneous (and possibly Pareto-efficient) interactions in a context in which, alongside the competitive mechanism of the market, there exists a mechanism of command working within the firm.

Some forty years after its publication, Coase's paper has become the starting point for a new research program aiming to explain all the institutions of capitalism and their internal power relations. This research program has been developed, in particular, by the new institutional economics. In my interpretation of this school of thought, research has developed along two distinct lines. In the former, Coase's intuition has been developed by denying the existence of real authority relations within the firm and by explaining the mechanism of command as a specific form of competition. The main exponents of this line of research are Alchian and Demsetz. In the second approach, the costs and benefits of competition and command have been analyzed systematically in an attempt to determine the virtues and vices of markets and hierarchies. Oliver Williamson's transaction costs economics and the property rights theory of Sanford Grossman, Oliver Hart, and John Moore are the main contributors to this line. ${ }^{1}$ Outside of new institutional economics, this research on power and the institutions

\footnotetext{
${ }^{1}$ In Palermo (2000), I argue that new institutional economics fails both in its attempts (1) to theoretically characterize the capitalist firm and (2) to analyze power relations in capitalism. In Ankarloo and Palermo (2004), we focus the critique on Williamson's transaction costs economics.
} 
of capitalism has been developed, in particular, by exponents of radical political economics, such as Samuel Bowles and Herbert Gintis, and of the institutional school, such as Victor Goldberg.

Although all these approaches have confronted each other in harsh polemical tones, my thesis is that the common acceptance of neoclassical methodology (and its implicit ontology) has allowed rich exchanges between them and has produced a convergence toward a common conception of power, as an exception to Walrasian competition. By contrast, Marxist contributions, based on a different method, have remained mainly at the margins of the debate and, when discussed explicitly, have often been misinterpreted and read with neoclassical lenses. This problem does not involve only historians of economic thought. Rather, I argue that the neoclassical method engenders a narrow conception of power as a purely interpersonal relation, which incorporates all the contradictions noted by Marx against the bourgeois political economy: its ahistoricity, its inability to explain social relations and causal mechanisms that cannot be reduced to intentional choice, and its focus on exchange rather than production.

I begin by reviewing the main theoretical approaches developed in the debate. Then, I single out the common methodological and ontological traits of these approaches, and I propose a representation in terms of set theory of their different positions concerning the extension of power relations in capitalism. Finally, I criticize this conception of power and contrast it with an alternative conception based on Marx's understanding of power and exploitation as social, rather than interpersonal, relations.

\section{The debate on power}

\section{The contractual approach of Alchian and Demsetz}

The idea that capitalism is characterized by the absence of any substantial power relations among individuals has been vigorously defended by Alchian and Demsetz (1972). Their paper is one of the most frequently cited contributions to interpersonal relations within the firm and has become the starting point for a new theoretical approach. In their "property rights approach", they explicitly deny the existence of any form of power or authority even in contexts in which, according to many, these forms are clearly manifest.

The authors consider production within the firm the result of the cooperation of individuals belonging to a team. The essential feature of team production is the impossibility of determining the relative contribution of each component of the team to the final production, which makes it difficult (1) to fix the efficient remuneration of the different work activities and (2) to prevent negligent and free-riding behaviors within the team. Such difficulties raise a problem of monitoring. Based on the assumption that the benefits of monitoring (the increase of overall productivity) are greater than its costs (the wage of the monitor), it follows that there is an incentive to establish a monitor. The monitor, however, has no real power over the other members of the team because he is subject to the same discipline imposed by market competition: he would be replaced as soon as another member of the team offered the same monitoring activity at a lower price. In this way, Alchian and Demsetz bring all the relations within the firm back to market relations and show that hierarchy within the firm is only apparent. This is how they discuss the employer-worker relationship.

It is common to see the firm characterized by the power to settle issues by fiat, by authority, or by disciplinary action superior to that available in the conventional market. This is delusion. The firm 
does not own all its inputs. It has no power of fiat, no authority, no disciplinary action any different in the slightest degree from ordinary market contracting between any two people. I can "punish" you only by withholding future business or by seeking redress in the courts for any failure to honor our exchange agreement. That is exactly all that any employer can do. He can fire or sue, just as I can fire my grocer by stopping purchases from him or sue him for delivering faulty products. (Alchian and Demsetz 1972, p. 777)

According to Alchian and Demsetz, the reason power relations should have no place in theory is that they do not exist in reality. Additionally, the opposition between firms and markets is only illusory. The market is universal, and perfect competition is always at work, even within the firm. The firm is nothing but a particular form of the market - one in which price is not continually re-negotiated, although the outcome is as if it were.

This position has been abundantly criticized by Marxist historians and radical economists who, in contrast, see the organization of the firm as strictly dependent on the question of power (Braverman 1974, Marglin 1974, 1975, Edwards 1979). But perhaps the best way to appreciate the limits of this approach is by following its internal development and its inevitable dead end.

To deny the existence of power relations within the firm, Alchian's pupil, Stephen Cheung, finds nothing better than denying the existence of the firm itself as an object of the social realm. In his view, what we generally call a "firm" is, in fact, simply a complex nexus of market contracts. The firm itself is a sort of market and is thus theoretically indistinguishable from it. Hence, the concept of the firm is unimportant and theoretically useless. No one is clearer than the author himself:

\begin{abstract}
It is often the case that the entrepreneur who holds employment contracts (and it is not clear whether it is the entrepreneur who employs the worker or the worker who employs the entrepreneur) may contract with other firms; a contractor may sub-contract; a sub-contractor may sub-sub-contract further; and a worker may contract with a number of "employers" or "firms". ... With this approach the size of the firm becomes indeterminate and unimportant. (Cheung 1987, p. 57)
\end{abstract}

If we cannot in any meaningful economic sense identify "firms", as separate entities, we do not know what a firm is when we see one in the real world. (Cheung 1992, p. 56)

Cheung's contribution is peculiar: he assumes that markets are universal and everlasting and, on this basis, carries Alchian and Demsetz's approach to its logical conclusion. Faced with the inevitable conflict between his theory and reality, Cheung rejects, on theoretical grounds, the existence of the reality he wished to explain. In his theory of the firm, firms do not exist! ${ }^{2}$

\title{
Williamson's transaction costs economics
}

Williamson's $(1975,1985,1994,1996)$ contributions constitute the most systematic attempt to approach the problem of institutions within new institutional economics. His market/hierarchies framework is explicitly defined within an individualist methodology and is developed by means of neoclassical analytical tools. However, Williamson explicitly distances himself from the approach of Alchian and Demsetz:

The argument that the firm "has no power of fiat, no authority, no disciplinary action any different

\footnotetext{
${ }^{2}$ Gary Becker's (1992, p. 68) comment to Cheung (1992) is sharp: "We generally know a firm when we see one".
} 
in the slightest degree from ordinary market contracting" (Alchian and Demsetz, 1972, p.777) is exactly wrong: firms can and do exercise fiat that markets cannot. (Williamson 1994, p. 325)

In Williamson's theory, firms are explained by determining the conditions that make a centralized OS more efficient than the market in a context of positive transaction costs. His method can be described as follows. He assumes "for expositional convenience, that in the beginning there were markets" (1975, p. 20) and, through successive exercises in comparative statics, introduces non-market institutions - based on different forms of hierarchy and authority - every time the market fails to allocate resources efficiently. Finally, by interpreting these comparative statics exercises as if they described a real historical process, Williamson provides his explanation of the existing institutional configuration of modern capitalist economies.

In this approach, markets and hierarchies are considered alternative instruments to the same end (to complete transactions), and their existence is explained in terms of their relative efficiency. If markets and hierarchies coexist in reality, it is because transaction costs prevent either of them from solving the entire allocation problem efficiently. Their relation is thus one of substitution. Once hierarchy is introduced, the (virtual) process of substitution proceeds until the economic benefits of centralization exceed the economic costs. In this way, Williamson explains not only the nature of the firm but also its boundaries because the optimal degree of centralization defines the optimal dimension of the firm.

Williamson's "market and hierarchies" framework is built on three theoretical categories: (1) opportunism, (2) bounded rationality, and (3) asset specificity. The simultaneous presence of (1), (2), and (3) produces transaction costs and prevents any single institution from allocating resources efficiently. The advantages of hierarchy over the market stem from the fact that hierarchy (1) reduces opportunism (both by means of authority and by stimulating solidarity), (2) attenuates problems stemming from bounded rationality (by facilitating adaptive sequential decision-making processes in situations in which contracts on the contingent states of nature are not possible and spot markets are risky), and (3) lowers bargaining costs caused by asset specificity (both through authority and by generating convergent expectations between the parties). The benefits of markets with respect to hierarchy include (1) the incentive mechanism of competition and (2) the growing diseconomies associated with hierarchical organization.

The assumption of bounded rationality as an initial category of Williamson's framework is problematic and, as we will see, is abandoned in the development of the new property rights school. In fact, this assumption conflicts with the fundamental assumption of Williamson's method, namely that institutional evolution follows economic efficiency. Put simply, on the one hand, individuals are supposed to be rationally bounded; on the other hand, their sub-optimal decisions are supposed to select optimal institutional configurations (cf. Mark Granovetter 1985, Geoffrey Hodgson 1993).

The first application of the market and hierarchies framework concerns the work relation. As Christos Pitelis (1991, p. 13) notes, this application is particularly important because only the work relation can explain the emergence of hierarchies from a situation of pure markets. All other applications of Williamson's framework (vertical integration, Mform, conglomerates) presuppose the existence of the firm and thus address the problem of the evolution of the firm, not its origins. The (hierarchical) work relation represents, in the story that starts "in the beginning there were markets", the first suppression of the market. All other changes in the internal structure of the firm and in the relations among firms are subsequent and presuppose a certain degree of hierarchy (i.e., the existence of a work relation). If at time 0 there were only markets, at time 1 there are markets and hierarchical work relations (i.e., firms). Then, from time 2 onward, the more complex forms of power 
relations can develop.

The importance of the work relation in the explanation of the firm makes Williamson's framework unlike Alchian and Demsetz's approach. Williamson's framework implies (1) a clear-cut distinction between the firm and the market based on the presence/absence of hierarchical relations and (2) a distinction between the work relation and other economic relations (such as the grocer-customer relation).

\section{The property rights approach of Grossman, Hart, and Moore}

The new theory of property rights (or simply "the theory of property rights") developed by Grossman, Hart, and Moore finds its inspiration in the original contribution of Alchian and Demsetz (1972). At the same time, it aims to overcome the lack of formal analysis of transaction costs economics, whose arguments have been developed mainly verbally (Grossman and Hart 1986, Hart 1990, 1995, Hart and Moore 1988, 1990, Moore 1992). As far as the issue of power is concerned, this theory is closer to the approach of Williamson (so much so that it is often presented as a sophisticated version of it) and reaches, in many ways, quite opposite conclusions with respect to the original property rights theory of Alchian and Demsetz.

Like transaction costs economics, the property rights school assumes an imperfect DMC in which contracts are necessarily incomplete. However, contract incompleteness depends solely on imperfect information, as in Alchian and Demsetz's approach, unlike Williamson's theory, in which it also depends on bounded rationality. According to Hart (1990), the problem is not that agents are not capable of conceiving of all possible contingencies but rather that it is impossible, or extremely costly, for a third party (a tribunal) to verify the execution of the contract. In other words, individuals are not bounded in their cognitive abilities but in their ability to communicate to a third party the terms of their agreement. Bounded rationality is thus unimportant for a theory of institutions. Therefore, this approach overcomes the contradiction between rationally bounded individuals and efficient institutional arrangements that characterizes Williamson's framework.

Grossman, Hart, and Moore analyze the problem of when transactions should be conducted within a firm or through the market. They classify contractual rights into two categories: specific and residual rights. The former are the rights explicitly specified in the contract; the latter are the rights to use assets according to one's wishes in all cases not mentioned in the contract. Residual rights are conferred by ownership. The owner of an asset can decide how it should be used and by whom (of course, within the constraints imposed by law and specific contracts). In particular, he is entitled to prevent the other party from using his assets in case of disputes. When, for party $A$, the cost of listing all specific rights over an asset of party $B$ is high, it might be optimal for party $A$ to purchase all residual rights. In this way, by assuming ownership of the specific asset, $A$ acquires the residual rights of control over it and can dispose of it as he wishes.

With this classification, the authors provide a straightforward definition of the firm and its boundaries with the market. A firm is identified with the physical assets its owners control. If two assets have the same owner, then they form a single, integrated firm; if they have different owners, then they form two separate firms, and the relation between them is a market one. Decisions about integration or non-integration are important because control over assets gives the owner decision-making power in the event of unforeseen contingencies. This situation has consequences both on the grounds of efficiency and on the grounds of power relations. From the viewpoint of efficiency, this approach studies how changes in ownership 
affect the incentives of both workers and owner-managers. With respect to the famous Coase (1960) theorem, contract incompleteness implies that the distribution of property rights has efficiency consequences. In contrast to transaction costs economics, Grossman, Hart, and Moore argue that the relevant comparison is not between the non-integrated outcome and the complete contract outcome; this would assume that integration yields the outcome that would arise under complete contracts. In a context of imperfect information and asset specificity, however, integration does not remove the incentives for opportunistic behavior; it simply modifies them depending on which party purchases residual rights. In any case, opportunism creates distortions that prevent the theoretical first-best solution - defined under complete contracts - from being obtained. Therefore, the relevant comparison is between three necessarily inefficient situations: non-integration and integration with either $A$ or $B$ acquiring residual rights.

Ownership of physical assets, however, is a matter not only of efficiency but also of power. According to this approach, the power of the boss over the worker is a consequence of his ownership of physical assets within a context of imperfect information. As Moore (1992, p. 496-7) puts it, "A boss exerts authority over workers because, in the event of a dispute, he can deny access to important physical assets". This solves the paradox of Alchian and Demsetz's grocer, based on the assumption that the work relation is not qualitatively different from any other market relation:

When a customer "fires" Alchian and Demsetz's grocer, the grocer (being a separate contractor) gets to keep the store; whereas if the grocer were an employee of the customer, the customer (the boss) could deny the grocer (the worker) access to the store, and could hire another grocer on the spot labor market. (Moore 1992, p. 497)

Methodologically, there are no significant differences between the approach of Grossman, Hart, and Moore and the contractualist one. However, their theoretical treatment of imperfections leads to opposite conclusions, to the point that Hart (1995, p. 5) suggests, "Given its concern with power, the approach proposed (...) has something in common with Marxian theories of the capitalist-worker relationship". We will see, however, that this similarity is only formal and that the different method followed by Marx, which is not based on "imperfections", leads to a completely different conception of power relations in capitalism.

\section{The radical political economics of Bowles and Gintis}

The "post-Walrasian" approach of Bowles and Gintis is an attempt to show that power relations are not confined within the firm but exist in competitive markets as well (Bowles 1985, Bowles and Gintis 1988, 1993a, 1993b, 2000). Bowles and Gintis define competition as a situation characterized by free entry and large numbers of buyers and sellers but not by market clearing. With this definition, the authors demonstrate that even in competitive equilibrium (with non-clearing markets), a market economy sustains a system of power relations among agents (a competitive equilibrium is a situation in which actors are incapable of improving their position by altering variables over which they have control). This result is obtained by relaxing one of the assumptions of the Walrasian DMC that Bowles and Gintis (like Grossman, Hart, and Moore) consider the most implausible: the assumption that contract enforcement by a third party is costless and unproblematic.

Bowles and Gintis (1993a, p. 325) define power as "the capacity of some agents to influence the behavior of others to their advantage through the threat of imposing sanctions". 
The absence of power relations in the Walrasian model is a consequence of the condition that supply equals demand, which implies that each agent loses nothing by abandoning his optimal transaction in favor of his next best alternative. In equilibrium, the cost to agent $B$ of foregoing an exchange with agent $A$ is zero, so $A$ cannot affect $B$ 's wellbeing by terminating the relation. Hence, Bowles and Gintis continue, $A$ has no power over $B$. More generally, the fact that no agent can impose sanctions on other agents in Walrasian equilibria implies that the economy works without any underlying power relation among agents.

If contract enforcement is problematic, however, the picture changes radically. In the case of the employer-worker relationship, for instance, "while the employer's promise to pay the wage is legally enforceable, the worker's promise to bestow an adequate level of effort ... is not" (Bowles and Gintis 1993a, p.333). Other examples studied by Bowles and Gintis are the relationships between an owner and manager, a lender and borrower, and between parties in international exchanges (Gintis 1989, Bowles, Gintis, and Gustafsson 1993, Bowles and Gintis 1994). In all these cases, competitive equilibrium is characterized by non-clearing markets, and agents on the short side of the market have power over agents on the long side with whom they transact (where excess supply exists, the demand side is the short one, and vice versa). The cause of this power relation is that the agents on the long side who are lucky enough to enter the relation with agents on the short side enjoy a "rent" (defined as the difference between the utility they obtain due to the transaction and the utility they will have if the transaction terminates), which is costly for them to lose. The fact that within imperfect DMCs, perfectly competitive markets do not necessarily clear produces an asymmetry between the two sides of the market, which, in turn, conditions interpersonal relations between single buyers and sellers.

In the case of the work relation, employers are on the short side of the labor market, and workers are on the long one. Employers thus have power over workers, and workers enjoy the so-called "employment rent" (similarly, Bowles and Gintis show that creditors have power over debtors, and owners of enterprises have power over managers). This rent is the instrument by which the employer places the worker under constant threat and pushes him to provide an adequate level of effort at work.

Bowles and Gintis' theory indirectly sheds light on the theoretical consistency of Alchian and Demsetz's claim that intra-firm relations are power-free. In fact, within nonclearing markets, contrary to what Alchian and Demsetz assume, free-contracting engenders power relations between the parties. The problem of Alchian and Demsetz's approach can thus be seen as follows: to say that the firm is a form of (competitive) market is not sufficient to prove that intra-firm relations are power-free simply because, as Bowles and Gintis demonstrate, perfectly competitive markets within an imperfect DMC can still involve power. If Alchian and Demsetz had remained coherent with their imperfect DMC, they would have realized that, in an imperfect grocers market, they could no longer fire their grocer at zero cost.

With respect to new institutionalism, Bowles and Gintis provide a completely different picture of capitalism. They show that (non-Walrasian) competitive equilibria are generally characterized by involuntary unemployment and by wage differentials based on gender or race (or on other characteristics that have nothing to do with productivity), that the democratic firm is superior to the capitalist one, and that capitalism is technologically inefficient. Most importantly, the result that power relations exist even under voluntary market exchange collapses the picture of a harmonious society that is provided by standard Walrasian economics and reconstructed by new institutional economics. Outside the Walrasian world, when markets do not necessarily clear, the market can no longer be seen as an arena of free interactions devoid of coercion, as liberal political philosophy suggests. Notwithstanding 
these theoretical differences, Bowles and Gintis' conception of power coincides with that of new institutional economics: power is understood as a consequence of imperfections and is analyzed by introducing transaction costs in an otherwise perfect DMC.

Methodologically and theoretically, there is also a large convergence between Bowles and Gintis' approach and the efficiency wages literature, focusing on workers' "shirking" in the presence of imperfect information and incomplete contracts (Shapiro and Stiglitz 1984, Akerlof and Yellen 1986). In both cases, a wage higher than the market clearing one is a device to induce the worker to work harder than he wishes. The only difference is that radicals note the implications in terms of power relations, whereas this branch of new Keynesianism insists on inefficiencies (rigorously speaking, this issue has to do with productivity, not with efficiency, because total output is increased by increasing the amount of one input, namely labor). However, they share the idea that imperfections are the causal factors of power and inefficiency. In the words of Bruce Greenwald and Joseph Stiglitz (1993, p. 24), "Modern Keynesians have identified these real world 'imperfections' as the source of the problem: leaving them out of the model is like leaving Hamlet out of the play".

\section{Goldberg's institutional perspective}

Things are no different with Goldberg's $(1976,1980)$ theory, which aims to build a bridge between new institutional economics and radical economics (Goldberg takes Williamson and Richard Edwards as spokespersons of these economic schools). Although he is close to the old American institutional tradition, Goldberg develops this exercise by following methodological individualism. First, however, let us consider Edwards' position.

By explicitly referring to Marx (1867), Edwards reconsiders the distinction between labor and labor power: labor power, which is the commodity that the employer buys, is the capacity to perform certain types of productive activity; labor is the active, concrete process performed by the worker. Actual labor activity is determined not only by labor power but also by the ability of the employer to extract labor from labor power. In Edwards, as well as in Marx, this distinction is used to explain exploitation (exploitation is seen here as a manifestation of economic power).

The process of the extraction of labor from labor power has been the object of a wide research program within the Marxist-radical tradition. Edwards, in particular, notes that in this concrete process, there may be a discrepancy between what the employer buys in the market and what he needs for production. In Goldberg's reading of Edwards, this discrepancy is due to imperfections in the DMC. He thus assumes a DMC of imperfect information, opportunistic individuals, costly contract enforcement, and historical time. In such an imperfect DMC, the extraction of labor from labor power is problematic because imperfections prevent the parties from precisely knowing, at the time of contracting, the labor that will be extracted in the labor process. According to the author, this situation gives rise to discrepancies between promise and execution, making room for the exercise of power. In other words, Edwards's claim that the labor contract is exploitative is not interpreted as a consequence of the class structure of the economy, as Edward himself suggests, but as a consequence of some empirical specificity of the work relation, such as the fact that working takes time and that information in the workplace is not perfect. The empirical attributes of the work relation are interpreted as causes of power in capitalism.

However, Goldberg continues, a discrepancy between promise and execution may arise every time a relation between two parties is not instantaneous, as in the Walrasian world. Therefore, it is not peculiar to the employment relation, as Marxists contend, but 
characterizes, to varying degrees, most exchange relations (Goldberg 1980, pp. 252-3). Goldberg concludes that power relations are not confined within the firm because an incentive not to keep a promise may emerge in several types of contractual relations, even outside the firm.

Also in this case, power relations exist only if contracting is problematic, and problematic contracting is a consequence of imperfections in the DMC. Rather than a bridge between new institutionalism and Marxism, Goldberg's theory is a neoclassical interpretation of Marx, which leads to a conception of power that, in many respects, is the opposite of the Marxian one. Theories of value and exploitation are not seen as essential aspects of Marx's work of the demystification of the capitalist mode of production but as useless social notions without implications in terms of interpersonal power relations. As I will show, for Marx, capitalist exploitation has nothing to do with a discrepancy between promise and execution. On the contrary, Marx shows that capitalists promise to exploit workers, and the point is that they generally keep this promise.

\section{The terms of the debate}

\section{Common ontological premises}

All the approaches discussed above share the idea that power relations exist only within imperfect DMCs. Authors who explicitly adhere to the liberal doctrine believe that the perfect DMC is the rule in reality. In their view, this justifies the fact that economic theory ignores power relations, at least in its general formulation. By contrast, their rivals in the debate on power consider the Walrasian DMC unrealistic. With asymmetric information, uncertainty, historical time, bounded rationality, or other imperfections, they argue, interpersonal relations necessarily involve power.

Ontologically, these apparently competing theories develop the same conception of reality, according to which the existence of power depends on the features of the DMC in which agents interact. In a perfect DMC, there is no room for power relations: the internal structure of the firm is irrelevant, and competition clears all markets; therefore, no one can have power over anyone else. In imperfect DMCs, by contrast, intra-firm relations affect the firm's performance, and markets do not necessarily clear. In these circumstances, they argue, power relations can emerge both within the firm and within the market. Therefore, in all these theories, imperfections are the cause of power relations. Eliminate them, these authors maintain - either implicitly or explicitly - and power relations disappear.

The problem of power is thus an empirical one, and its solution is to be found in the relevance of imperfections in the real world. According to this ontology, economic reality is split into two distinct closed systems: a system with no imperfection, in which interpersonal relations are governed by perfect competition, and a system with imperfections, in which power matters.

Although this ontology remains mostly implicit in the discourse of mainstream economists, it is the sole justification of the neoclassical methodology, according to which economic reality must be explained by two (incompatible but complementary) sets of models: a model of Walrasian competition, explaining the relations within the perfect DMC, and a set of models of economic power, explaining interpersonal relations within the parts of the system characterized by imperfect DMCs (it goes without saying that the former defines the body of economic theory, whereas the latter serves to explain what the former cannot).

At first sight, authors who consider imperfections pervasive in the real world do not 
need this ontological assumption. Within the radical school, Ernesto Screpanti (2001, p. 145) is explicit on this point. He begins by defining a complex DMC characterized by bounded rationality, imperfect information, uncertainty, and various externalities and then affirms, "Perfect and atomistic competition cannot exist in this world, even as a limit case - I mean the neoclassical competition that eliminates all inefficiencies and power hubris". In his view, the perfect DMC is only a theoretical benchmark with no empirical counterpart. It is not an ontological entity of capitalist economies but a methodological tool of the economist. The model of perfect competition does not serve to understand how the real world works but how it does not work. On the contrary, to describe real capitalist economies, one must assume an imperfect DMC. With this interpretation, however, it is not clear why Screpanti and other neoclassical radicals choose this abstract fiction with no ontological role as the theoretical benchmark of their supposedly more realistic exercises.

\section{The ontology of power and competition}

This underlying ontology explains why theoretical investigations of power relations start from the firm, a domain in which hierarchy and authority are so evident as to be considered the phenomena to explain. In a first stage of the debate, the fact that market relations have been depicted as power-free has led to an analysis of power (within the firm) as an exception to the general model (of the market). This situation has led to the question of "the boundaries of the firm", as if the firm, with its authority relations, were antagonistic to the market, with its power-free relations. In this way, the complementary role of the firm and the market in capitalism is necessarily lost. The successive step in the debate, consisting of questioning the assumption that power is effectively confined within the firm, finally leads to a more accurate redefinition of the problem. The theoretical question becomes the following: where are the boundaries of economic power? To put it in the antagonist terms of this approach, where is the demarcation line between power and power-free relations?

With this narrow definition of the problem, the sphere of existence of power relations and that of power-free relations can be represented in terms of set theory. The set of existing economic relations can be divided into two disjoint subsets according to the absence/presence of imperfections in the DMC. The borderline between these subsets separates the parts of the world in which interpersonal relations are governed by Walrasian competition from those in which they are governed by power. This ontology can be represented graphically with the convention that the perfect DMC is on the left of the borderline and imperfect DMCs are on the right.

Figure 1. The boundaries of economic power

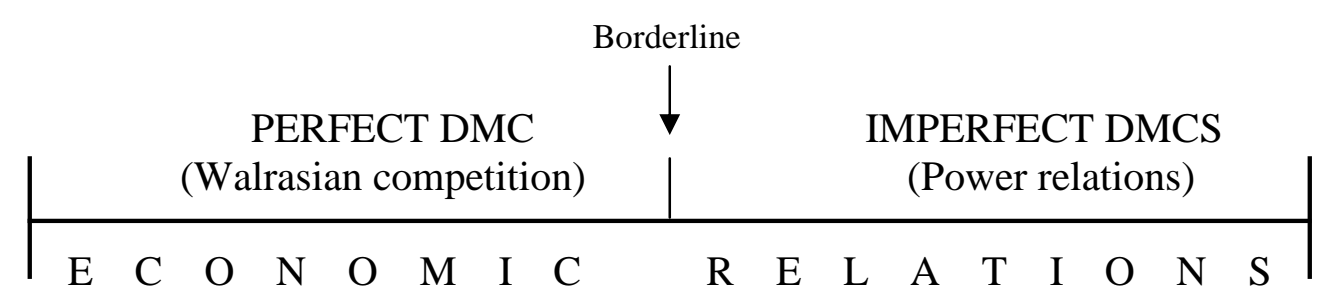


If we allow the borderline to move from left to right, the sphere of existence of power relations is progressively compressed. As limit cases, if the borderline is at the left boundary of economic relations, we have a conception according to which power relations embrace the entire economy. If it is at the right boundary, we have a conception of the economy as involving no power relations, formally represented by the general equilibrium model.

\section{Liberals, radicals, and the boundaries of power}

In this representational scheme, the approach of Alchian and Demsetz is the most radical one on the right-hand side. They see perfect competition everywhere, even when this mode of interaction is actually suppressed by other economic mechanisms.

Figure 2.

The terms of the debate

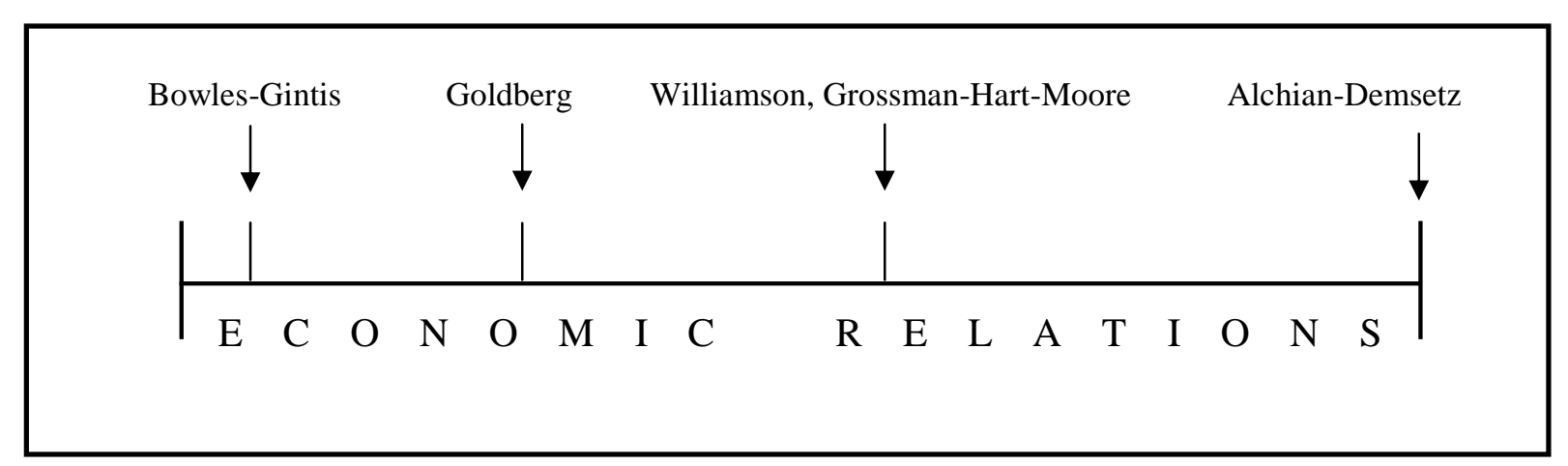

For this reason, they deny the existence of any power relation in the economy and compress the sphere of existence of power into the empty set. Their underlying DMC, however, is ambiguous. On the one hand, to explain the firm, Alchian and Demsetz explicitly introduce imperfect information in the DMC; on the other hand, they implicitly assume a perfect DMC when they claim that the employer has no real power over his workers. Faced with this contradiction, the authors remain caught in the middle. However, Cheung takes a well-defined route: to coherently defend the thesis that there is no power in capitalism, he returns to the perfect DMC, a context in which power relations disappear but the firm disappears as well, exactly as in the general equilibrium model.

In contrast to this position, new institutional economists, such as Williamson, Grossman, Hart, and Moore, recognize that power relations do exist. They explicitly define imperfect DMCs to explain the firm and identify power relations with intra-firm relations. For this reason, they restrict the analysis of power relations to the particular forms that these relations acquire within the firm, namely, authority and hierarchy. At the same time, they concede that outside the firm, in the market, there is no room for power. Like Alchian, Demsetz, and Cheung, they assume that the boundaries of power coincide with those of the firm. Unlike these authors, however, Williamson, Grossman, Hart, and Moore do not see the firm as an implicit (perfectly competitive) market but rather as an alternative (and, under certain conditions, more efficient) allocative mechanism.

Bowles and Gintis, on the one hand, and Goldberg, on the other, make a further step to the left and show that power relations exist even beyond the boundaries of the firm, to the 
extent that markets are imperfect. It is not clear whether Bowles and Gintis push the borderline between power and perfect Walrasian competition to the far left boundary of economic relations. The authors explicitly contend that power relations are ubiquitous in real capitalist economies, which might suggest that there is no room for power-free relations in their conception. However, this is only because they see imperfections as pervasive in the real world. Just as for their less radical colleagues, the sphere of existence of power relations coincides with the diffusion of imperfections in the DMC. Therefore, if it happens in a particular market that demand equals supply, then their theory implies that within such a subset of the economic realm, interpersonal relations are power-free. ${ }^{3}$ Therefore, neoclassical radicals do not challenge the orthodox conception of power relations. Their radicalism consists simply of moving the borderline a bit more to the left. At the same time, however, it is entirely internal to the logic of mainstream economics, a logic according to which imperfections are the cause of power relations.

\section{A Marxist critique}

\section{Imperfections and the ahistorical conception of capitalism}

The idea that imperfections in the DMC are the cause of capitalist power relations engenders a tension with history. Before capitalism, in this conception, there was no feudalism or other modes of production, but Léon Walras. Indeed, the nature of capitalist power relations is not studied as a transformation of the power relations that regulated the modes of production that preceded capitalism. Rather, it is explained as a deviation of real capitalism from the abstract model of complete and perfect markets.

Bounded rationality, imperfect information, and historical time, however, are not specific to capitalism. Rather, they are features of all human relations in any historical context. Therefore, according to this logic based on imperfections, power relations are a constant of any social system. This is not the time to discuss whether this statement is right or wrong. For instance, in the Marxist tradition, all societies based on a certain division of labor and a degree of specialization of their members are considered to be necessarily based on power relations. The problem involves the attempt to explain historical processes by means of ahistorical categories.

Such a method implies that power relations have always existed, even before the historical development of market relations and economic competition, although they have become visible only with the historical development of capitalism (and the consequent possibility of conceiving a model of complete markets and perfect competition). Neoclassical theorists of power must consider themselves very lucky to live in the sole epoch in which everlasting power relations have finally become visible, as an exception to the Walrasian model.

The truth, however, is that market interaction and economic competition are not everlasting forms of social coordination. Markets have not always existed, and economic competition has become the main form of social coordination only in relatively recent times. If pre-capitalist systems with less developed or completely absent market relations were not regulated by economic competition, it cannot be because of market imperfections, as the

\footnotetext{
${ }^{3}$ Elsewhere, I have developed a Marxist view of power, and I have argued that capitalism is a system of power (Palermo 2007). Nevertheless, I would not locate my position on the far left boundary of economic relations because this representation presupposes an antagonism between power and Walrasian competition, which is meaningless from a Marxist perspective.
} 
neoclassical method implies, but because of a lack of market relations.

\section{Free contracting and the Eden of the innate rights of man}

For Marx, free contracting is one of the historical conditions of the emergence of proper capitalistic relations. As he writes, for a capitalist-worker relation to emerge, the laborer must be free in a double sense:

That as a free man, he can dispose of his labour-power as his own commodity, and that on the other hand he has no other commodity for sale, is short of everything necessary for the realisation of his labour-power (Marx 1867, Chap. 6).

Free contracting and the lack of the means of production are the two ingredients of capitalistic exploitation. There is no abuse or prevarication, no asymmetric information or bounded rationality, in the power relation of the capitalist over the worker. The fact that the worker must obey the capitalist is not even the essence of the problem for Marx. The power relation of the capitalist over the worker as individuals is simply a consequence of the relationship of exploitation that exists between their social classes. Therefore, Marx does not seek the coercive nature of capitalism in the interpersonal relationship between the single capitalist and the single worker but in the social mechanisms that separate the population in social classes and that reproduce such a social structure.

In capitalism, the worker is not obliged to exchange his labor power with the wage of a particular capitalist, but he is obliged to exchange his labor power with the wage of $a$ capitalist. If one follows an extreme individualist-voluntaristic approach, Alchian and Demsetz are right when they affirm that the worker is a free individual who can leave the capitalist whenever he wants. However, from a social perspective, the worker's freedom is very peculiar: he must obey a capitalist or choose another capitalist to obey (in fact, even this very peculiar choice exists only for particular categories of skilled workers, whereas unskilled workers can, at best, hope to be chosen by a capitalist). The worst thing that can happen to a worker in a society based on capital is to not find a capitalist wishing to command and exploit him. It is not a problem of uncertainty, bounded rationality, or asymmetric information. Rather, it is a form of social coercion imposed by class relations.

Of course, within Marxism, "imperfections" modify interpersonal power relations. However, they do not create them. If a worker is not well informed or his rationality is bounded, he might accept worse conditions than his colleagues. Yet, even the most rational and well-informed worker will never get a job if he is not ready to obey and to be exploited. This is why, theoretically, Marx does not need to introduce imperfections in the DMC to explain the exploitative nature of capitalism and the power relationship of the capitalist over the worker. If capitalism is a system of exploitation and power relations, it is not because contracts are imperfect or incomplete but because capitalism is based on free contracts. The problem is not that contracts are occasionally violated, as the neoclassical method suggests, but that they are generally respected.

By contrast, according to the neoclassical conception, a world of perfect information and free contracting is, by definition, a world free of power relations or, to use Marx's provocative expression, "the Eden of the innate rights of man". Power relations emerge only when contracts are not correctly executed. The fact that contracting agents might face completely different material constraints when they "freely" sign a contract is not seen as a potential cause of their contractual power relation. On the contrary, the implicit assumption is that contracts are signed in a vacuum in which only subjective choice matters. 


\section{Production, circulation, and the free trader vulgaris}

In capitalism, the terms of a contract are not determined simply by the wishes of the transacting parties. They are inevitably conditioned by the social context as well. The work contract, in particular, hides exploitative conditions that, according to Marx, are by nature social and do not necessarily appear directly at an interpersonal level. This is why he insists on the separation of the spheres of production and circulation.

In the sphere of circulation, capitalists and workers do not appear, in the first instance, as social entities, but simply as individuals who buy and sell commodities. However, before they are exchanged, commodities must be produced. It is only when we enter the sphere of production that the social nature of capitalists and workers becomes evident:

\footnotetext{
On leaving this sphere of simple circulation or of exchange of commodities, which furnishes the "Free-trader Vulgaris" with his views and ideas, and with the standard by which he judges a society based on capital and wages, we think we can perceive a change in the physiognomy of our dramatis personae. He, who before was the money-owner, now strides in front as capitalist; the possessor of labour-power follows as his labourer. The one with an air of importance, smirking, intent on business; the other, timid and holding back, like one who is bringing his own hide to market and has nothing to expect but - a hiding (Marx 1867, Chap. 6).
}

By investigating the sphere of production, Marx argued that the working class is exploited and that the capitalist class appropriates a value it has not produced. This form of social exploitation is also the main cause of the asymmetry between capitalists and workers in the workplace. The need to control and supervise the production process is a consequence of the problematic process of extracting living labor from workers' labor power. Marx discusses this process in different parts of Capital and explains how the organization of the firm and its worker disciplining mechanism evolve according to the needs of capital accumulation. He notes, for instance, that the development of cooperative factories and stock companies are very different processes in many respects, but they are two ways for each individual capitalist to obtain the same goal: delegating the extraction of living labor to other subjects (the manager in one case and the worker in the other) (Marx 1894, chapter 27).

Modern Marxists, such as Braverman (1974), Marglin (1974, 1975), and Edwards (1979), have developed this conception by discussing the evolution of class relationships and the development of different forms of power, authority, and hierarchy within capitalist firms in the twentieth century. Social exploitation and interpersonal power relations, in the work of these authors, are dialectically linked. On the one hand, exploitative class relations in society are the cause of the interpersonal power relations in the workplace; on the other hand, the evolution of the forms of power that prevail within capitalist firms modifies the overall rate of exploitation and class relations.

By contrast, in the neoclassical approach, based on the sole sphere of circulation, the worker is not exploited at all. On the contrary, for a power relation to exist between the worker and the capitalist, the worker must collect rent from the latter. This rent, in an equilibrium position, is the compensation for the nuisance of being commanded. Thus, like other commodities, power has its equilibrium price, defined as the amount of money used to compensate the worker to insure that he will not use his informative advantages opportunistically.

We can appreciate the distance between Marxism and the parts of the radical school based on methodological individualism and pure circulation. Both of them formally conclude that the capitalist has power over the worker. For Marx, however, this interpersonal power 
relation is a consequence of a social asymmetry in the sphere of production. For Bowles, Gintis, and their neoclassical colleagues, by contrast, it is a consequence of individual asymmetries in the sphere of circulation. For Marx, the individual capitalist has power over the individual worker because his social class is stronger than the working class. For radicalneoclassical economics, the capitalist has power over the worker because, at an interpersonal level, he is weaker than the latter and thus finds it convenient to buy his obedience.

Within the sphere of circulation, there can be no production of value but only an exchange of equivalents. Therefore, if, in an equilibrium position, the individual capitalist has power over the individual worker, in the neoclassical conception, it is only because he pays for it. Before the exchange, this production factor belonged to the worker, like the labor power that he sells to the capitalist. After the exchange, power passes to the hands of the capitalist, and its monetary equivalent passes to the hands of the worker.

To show that the capitalist has power over the worker during the working process, neoclassical economics must assume that the individual worker is not a member of the class of persons who have nothing to sell except their labor power. On the contrary, it must be assumed that he is a privileged person within this class (for instance, because of his human capital or because his work is difficult to monitor) who has something else to sell (his specific skills and his information asymmetries). Therefore, according to radical economists, pure sellers of labor power (common, unskilled workers) in a perfectly competitive labor market do not suffer any power relation because they have nothing to lose. Only skilled workers, or workers with specific capabilities or with information advantages, have wage privileges, which push them to give the maximum in the workplace and to accept a power relation under the employer.

This bizarre conception shows that, in contrast to the claim of radical economists, power can only be an exception in this approach; it cannot be the rule. If all workers were really specific and difficult to monitor because of widespread imperfections in the DMC, no competitive wage in the market would exist. Therefore, the threat of being fired and losing the employment rent would not be credible, and the capitalist would have no power over the worker. Remember that in this theory of power, just as in the efficiency wages theory, the worker has as an incentive to work hard only if a lower (perfectly competitive) wage prevails in the labor market. In other words, this theory can, at best, explain why some particular workers suffer a power relation from their employer, but it cannot explain why workers in general suffer a power relation from capitalists. Thus, this approach cannot provide a general theory of power relations in capitalism. On the contrary, the demonstration that some individual workers suffer a power relation rests on the assumption that standard workers suffer no power relation.

\section{Final remarks}

Although the substantive theories of power that I have considered differ to some extent, I have argued that their common methodology leads to the same general conception, according to which power is an exception to Walrasian competition.

The limits of this conception can be appreciated by considering the scientific question that these theories attempt to answer. The starting point of the debate is not the historical development of capitalist institutions but a theoretical model. In the Walrasian model, the firm is redundant, and power relations are invisible. These are the scientific problems to solve. The history of capitalism is not the object of the inquiry. Rather, the problem is to introduce firms and power in a model that works perfectly without them. In the debate on the 
nature of capitalist institutions, this problem has raised questions: why does the firm exist? Where are its boundaries with the market? In the debate on power, suggestions have been presented less explicitly, but the underlying questions are of the same type: Why do power relations exist? Where are their boundaries with Walrasian competition?

If the model of perfect and complete markets works without the firm, the only way to coherently introduce the firm is by making markets imperfect or incomplete. From the perspective of power relations, this means that power can only appear as a violation of the conditions of Walrasian competition. Power and competition are thus understood as alternative mechanisms of social coordination in a flat ontology in which the space occupied by one mechanism is necessarily subtracted from the other. The curious thing is that, notwithstanding this symmetry between power and competition, they are treated asymmetrically in concrete model building. Power and the firm are scientific problems, phenomena to explain. Competition and the market, by contrast, are starting points; they are assumptions that deserve no scientific explanation. This is why the nature of power and the firm has been the object of scientific discussion, whereas a debate on the nature of competition and the market has not even begun within mainstream economics.

To demonstrate the limits of this narrow conception of power based on the neoclassical method, I have contrasted it with Marx's conception of capitalism as a system of social relations based on power and exploitation. Marx's dialectic aims to explain the relation between the social condition of exploitation of the working class and the power relation suffered by the individual worker. By contrast, in the neoclassical conception, there is no exploitation (in fact, the exploited person might be the capitalist who pays rent, but surely not the worker who receives it). The only workers who really suffer power relations are those with a privileged set of endowments with respect to the army of pure sellers of labor power. The power relation suffered by the (qualified) worker, in this approach, is not caused by his participation in an exploited class but by his privileged position within this class. In a nutshell, the worker suffers a power relation not because of his social weakness but because of his individual strength.

Marx repeatedly criticized the bourgeois political economy for its tendency to analyze production with the lenses of circulation and for its inability to understand the historical development of the capitalist mode of production and the dialectical relation between social and interpersonal relations. Neoclassical theorists, even when declaring affinities with Marx, do not attempt to address these critiques. On the contrary, their models with imperfections are simply a more sophisticated version of the same old views of the "free trader vulgaris".

\section{References}

Akerlof, George, and Janet Yellen, ed. 1986. Efficiency wage models of the labor market. Cambridge: Cambridge University Press.

Alchian, Armen, and Harold Demsetz. 1972. Production, information costs and economic organization. American Economic Review 62(1): 777-95.

Ankarloo, Daniel, and Giulio Palermo. 2004. Anti-Williamson: A Marxian critique of New institutional economics, Cambridge Journal of Economics, 28(3): 413-29.

Becker, Gary. 1992. Comments to Cheung. In Contract Economics, ed. Lars Werin and Hans Wijkander, Oxford: Basil Blackwell.

Bowles, Samuel. 1985. The production process in a competitive economy: Walrasian, Marxian and neo-Hobbesian models. American Economic Review 75: 16-36.

Bowles, Samuel, and Herbert Gintis. 1988. Contested exchange: political economy and 
modern economic theory. American Economic Review 78: 145-50.

. 1993a. Power and wealth in a competitive capitalist economy. Philosophy and Public Affairs 21(4): 324-53.

1993b. The revenge of homo economicus: Contested exchange and the revival of political economy. Journal of Economic Perspectives 7(1): 83-102.

. 1994. Credit market imperfections and the incidence of worker-owned firms. Metroeconomica 45(3): 209-23.

. 2000. Walrasian economics in retrospect. The Quarterly Journal of Economics 115(4): 1411-39.

Bowles, Samuel, Herbert Gintis and Bo Gustafsson. 1993. Markets and Democracy: Participation, Accountability and Efficiency, Cambridge: Cambridge University Press.

Braverman, Harry. 1974. Labor and monopoly capital: The deregulation of work in the twentieth century. New York: Monthly Review Press.

Cheung, Stephen. 1987. Economic organization and transaction costs. In The New Palgrave: a Dictionary of Economics, ed. John Eatwell, Murray Millgate and Paul Newman, London: Macmillan.

. 1992. On the new institutional economics. In Contract Economics, ed. Lars Werin and Hans Wijkander, pp. 48-65, Oxford: Basil Blackwell.

Coase, Ronald. 1937. The nature of the firm. Economica 4(4): 386-405. 1960. The problem of social cost. Journal of Law and Economics 3: 1-44.

Edwards, Richard. 1979. Contested terrain: The transformation of the workplace in the twentieth century. New York: Basis Books.

Gintis, Herbert. 1989. Financial markets and the political structure of the enterprise. Journal of Economic Behavior and Organization 11: 311-22.

Goldberg, Victor. 1976. Toward an expanded economic theory of contract. Journal of Economic Issues 10(1): 45-61.

1980. Bridges over contested terrain: Exploring the radical account of the employment relationship. Journal of Economic Behavior and Organization 1: 249-74.

Granovetter, Mark. 1985. Economic action and social structure: the problem of embeddedness. Journal of American Sociology 91(3): 481-510.

Greenwald, Bruce, and Joseph Stiglitz. 1993. New and old Keynesians. Journal of Economic Perspectives 7(1): 23-44.

Grossman, Stanford, and Oliver Hart. 1986. The costs and benefits of ownership: A theory of vertical and lateral integration. Journal of Political Economy 94(4): 691-719.

Hart, Oliver. 1990. Is bounded rationality an important element of a theory of institutions? Journal of Institutional and Theoretical economics 146(4): 696-702. . 1995. Firms, contracts and financial structure. Oxford: Clarendon.

Hart, Oliver, and John Moore. 1988. Incomplete contracts and renegotiation. Econometrica 56: 755-85.

. 1990. Property rights and the nature of the firm. Journal of Political Economy 98(6): 1119-58.

Hodgson, Geoffrey. 1993. Economics and evolution: Bringing life back into economics. Cambridge: Polity Press.

Marglin, Stephen. 1974. What do bosses do? The origins and functions of hierarchy in capitalist production. Part 1. Review of Radical Political Economics 6(2): 60-112. . 1975. What do bosses do? The origins and functions of hierarchy in capitalist production. Part 2. Review of Radical Political Economics 7(1): 20-37. 
Marx, Karl. 1867. Capital: Critique of political economy. Vol. 1. The process of capitalist production. The Marx/Engels Internet Archive: http://www.marxists.org. . 1894. Capital: Critique of Political Economy, vol. 3, The Process of Capitalist Production as $a$ whole. The Marx/Engels Internet Archive: http://www.marxists.org.

Moore, John. 1992. The firm as a collection of assets. European Economic Review 36(2/3): 493-507.

Palermo, Giulio. 2000. Economic power and the firm in new institutional economics: Two conflicting problems. Journal of Economic Issues 34(3): 573-601. . 2007. The ontology of economic power in capitalism: Mainstream economics and Marx. Cambridge Journal of Economics 31(4): 539-61.

Pitelis, Christos. 1991. Market and non-market hierarchies: Theories of institutional failure. Oxford: Basil Blackwell.

Samuelson, Paul. 1957. Wage and interest: A modern dissection of Marxian economic models. American Economic Review 47: 884-912.

Screpanti, Ernesto. 2001. The Fundamental Institutions of Capitalism, London: Routledge.

Shapiro, Carl, and Joseph Stiglitz. 1984. Equilibrium unemployment as a worker discipline device. American Economic Review 74(3): 433-44.

Williamson, Oliver. 1975. Markets and hierarchies: Analysis and anti-trust implications. A study in the economics of internal organization. New York: The Free Press. 1985. The economic institutions of capitalism: Firms, markets, relational contracting. London: Macmillan. . 1994. Visible and invisible governance, American economic review, Papers and proceedings $84(2)$ : 323-6.

. 1996. The mechanisms of governance. Oxford: Oxford University Press. 